\title{
Annual Change Report 2006/2007
}

From July 1, 2006, to June 30, 2007

\author{
November 16, 2007
}

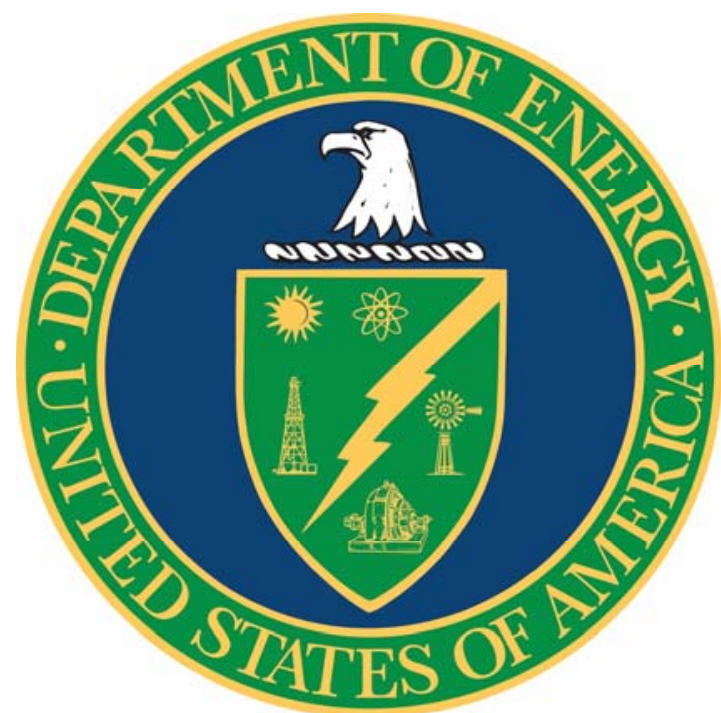

Prepared for:

The Department of Energy

Prepared by:

Washington Regulatory and Environmental Services

an affiliate of

Washington TRU Solutions LLC 


\section{Table of Contents}

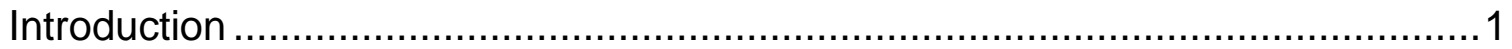

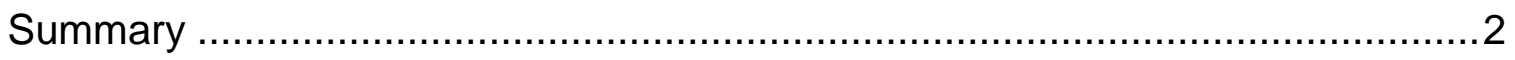

Table 1: Changes in WIPP Conditions or Activities Reportable under Title 40

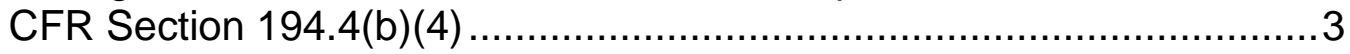

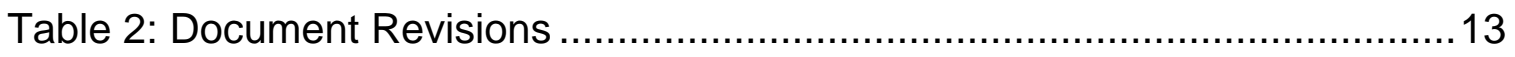

Table 3: Waste Emplacement Summary Report ......................................24

Table 4: Performance Assessment Software and Hardware Changes ..............27

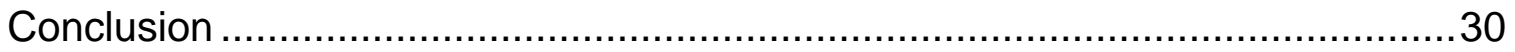

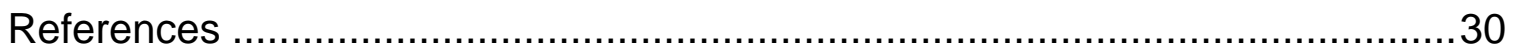




\section{Introduction}

As part of continuing compliance, the U.S. Environmental Protection Agency (EPA) requires the U.S. Department of Energy (DOE) to provide information on any change in conditions or activities pertaining to the disposal system since the most recent compliance application. This requirement is identified in Title 40 Code of Federal Regulations (CFR), Section 194.4(b)(4), which states:

"No later than six months after the administrator issues a certification, and at least annually thereafter, the Department shall report to the Administrator, in writing, any changes in conditions or activities pertaining to the disposal system that were not required to be reported by paragraph (b)(3) of this section and that differ from information contained in the most recent compliance application."

In meeting the requirement, the DOE provides an annual report each November of all applicable changes under the above requirement. This annual report informs the EPA of changes to information in the most recent compliance recertification (the 2004 Compliance Recertification). Significant planned changes must be reported to the EPA prior to implementation by the DOE. In addition, Title 40 CFR, Section 194.4(b)(3) requires that significant unplanned changes be reported to the EPA within 24 hours or ten days, depending on the severity of the activity or condition. To date, there have been no significant unplanned changes to the certification basis. Planned changes have been submitted on an individual basis. All other changes are reported annually.

Changes in activities or conditions are reviewed to determine if 40 CFR Section 194.4(b)(3) reporting is necessary. As indicated above, no significant unplanned changes were identified for the time period covered by this report. The enclosed tables list those items identified for reporting under 40 CFR Section 194.4(b)(4). The majority of the items described in this report are inspections, reports, and modifications to written plans and procedures for WIPP operations.

This report captures the summary of each change within four tables:

1. Table 1: Changes in WIPP Conditions or Activities Reportable under Title 40 CFR Section 194.4(b)(4)

2. Table 2: Document Revisions documents changes to relevant plans and procedures during the reporting period

3. Table 3: Waste Emplacement Summary Report documents the TRU waste inventory for the waste parameters identified in Table 4-10 of the CCA. The summary provides the total emplaced inventory in the repository as of June 30,2007 , and the inventory that was emplaced during the reporting period (July 1, 2006 to June 30, 2007)

4. Table 4: Performance Assessment Software and Hardware Changes documents the changes to relevant codes, software, and hardware that have occurred during the current reporting period

In accordance with the EPA's requests and feedback over the past eight years, this report incorporates many of the suggestions and guidance for capturing the appropriate level of detail and the layout of information with respect to the WIPP certification criteria. This report does not include all administrative changes to procedures. Examples of administrative changes to procedures that were not included are editorial changes, reformatting, correcting the title of references, correcting inconsistency within a procedure, and other changes that do not change the substance or intent of the document. 
Also requested by the EPA is the identification of any references previously entered into the EPA Docket system. This change is visible within the information in Table 1. Applicable references identify the EPA Docket Item Number (where available) for the specific information and add a general sentence identifying the change.

\section{Summary}

The DOE believes the changes reported in this version of the WIPP Annual Change Report do not represent significant changes in conditions or activities pertaining to the disposal system. 
Table 1: Changes in WIPP Conditions or Activities Reportable under Title 40 CFR Section 194.4(b)(4)

$$
\text { July 1, 2006, through June 30, } 2007
$$


Table 1: Changes in WIPP Conditions or Activities Reportable under Title 40 CFR Section 194.4(b)(4) July 1, 2006, through June 30, 2007

\begin{tabular}{|c|c|c|}
\hline $\begin{array}{l}\text { Certification } \\
\text { Criteria }\end{array}$ & $\begin{array}{l}\text { Implementing } \\
\text { Document or } \\
\text { Activity that } \\
\text { Changed }\end{array}$ & $\begin{array}{c}\text { Description of the Change and DOE Assessment of the Impact of the } \\
\text { Change }\end{array}$ \\
\hline 194.4 & Annual Change Report & $\begin{array}{l}\text { Letter from Department of Energy (DOE) to Environmental Protection Agency (EPA) } \\
\text { (December 11, 2006) resolving comments from the EPA in response to the } 2005 / 2006 \\
\text { Annual Change Report. Letter from DOE to EPA (March 12, 2007) identifying a change in } \\
\text { the } 2005 / 2006 \text { Annual Change Report. }\end{array}$ \\
\hline $\begin{array}{l}194.8 \text { Approval } \\
\text { process for Waste } \\
\text { Generator Sites for } \\
\text { Disposal }\end{array}$ & $\begin{array}{l}\text { Approval process for } \\
\text { Waste Generator Sites } \\
\text { for Disposal }\end{array}$ & $\begin{array}{l}\text { The EPA announced the availability of, and soliciting public comments for } 45 \text { days on, the } \\
\text { proposed approvals of the radioactive, remote-handled (RH), transuranic (TRU) waste } \\
\text { characterization programs implemented by the Central Characterization Project (CCP) at } \\
\text { Idaho National Laboratory (INL) and Argonne National Laboratory (ANL). This waste is } \\
\text { intended for disposal at the Waste Isolation Pilot Plant (WIPP) in New Mexico. These are } \\
\text { the first proposed approvals for the characterization of RH waste. The EPA evaluated the } \\
\text { characterization of RH TRU debris waste from INL-CCP and ANL-CCP during inspections } \\
\text { conducted the weeks of June } 12,2006 \text {, and September } 11,2006 \text {, respectively. }\end{array}$ \\
\hline $\begin{array}{l}194.8 \text { Approval } \\
\text { process for Waste } \\
\text { Generator Sites for } \\
\text { Disposal }\end{array}$ & $\begin{array}{l}\text { Approval process for } \\
\text { Waste Generator Sites } \\
\text { for Disposal }\end{array}$ & $\begin{array}{l}\text { Docket number EPA-HQ-OAR-2006-0597-0001. Proposed annual approval of the } \\
\text { Advanced Mixed Waste Treatment Projects (AMWTP) TRU Waste Characterization } \\
\text { program at INL. Posted July 31, 2006. }\end{array}$ \\
\hline $\begin{array}{l}194.8 \text { Approval } \\
\text { process for Waste } \\
\text { Generator Sites for } \\
\text { Disposal }\end{array}$ & $\begin{array}{l}\text { Approval process for } \\
\text { Waste Generator Sites } \\
\text { for Disposal }\end{array}$ & $\begin{array}{l}\text { The EPA conducted Baseline Inspection No. EPA-INL-CCP-RH-6.06-8 of the CCP waste } \\
\text { characterization (WC) program for RH TRU waste at the DOE INL. EPA conducted a } \\
\text { baseline inspection of the site's program to characterize RH TRU wastes proposed for } \\
\text { disposal in the WIPP. } \\
\text { Follow-up inspection on August 9, } 2006 \text { for the purpose of assessing mass } \\
\text { spectrometry data used to support one element of the INL RH WC program. } \\
\text { Follow-up inspection on August 29, } 2006 \text { for the purpose of resolving open issues from } \\
\text { the previous two inspections. EPA approved the disposal of retrievably stored, RH } \\
\text { TRU, debris waste. }\end{array}$ \\
\hline $\begin{array}{l}194.8 \text { Approval } \\
\text { process for Waste } \\
\text { Generator Sites for } \\
\text { Disposal }\end{array}$ & $\begin{array}{l}\text { Recertification of } \\
\text { Hanford Program }\end{array}$ & $\begin{array}{l}\text { Letter from DOE to EPA (January 9, 2007) pertaining to the review and concurrence of the } \\
\text { DOE recertification letter for the Hanford site based on the results from audits A-06-18 and } \\
\text { A-06-019. }\end{array}$ \\
\hline
\end{tabular}


Table 1: Changes in WIPP Conditions or Activities Reportable under Title 40 CFR Section 194.4(b)(4) July 1, 2006, through June 30, 2007

\begin{tabular}{|c|c|c|}
\hline $\begin{array}{l}\text { Certification } \\
\text { Criteria }\end{array}$ & $\begin{array}{l}\text { Implementing } \\
\text { Document or } \\
\text { Activity that } \\
\text { Changed }\end{array}$ & $\begin{array}{c}\text { Description of the Change and DOE Assessment of the Impact of the } \\
\text { Change }\end{array}$ \\
\hline $\begin{array}{l}194.8 \text { Approval } \\
\text { process for Waste } \\
\text { Generator Sites for } \\
\text { Disposal }\end{array}$ & $\begin{array}{l}\text { Recertification of INL } \\
\text { Program }\end{array}$ & $\begin{array}{l}\text { Letter from EPA to DOE (January 12, 2007) approving the disposal of retrievably stored, RH } \\
\text { TRU, debris waste by INL-CCP. EPA Docket No: A-98-49, Item II-A4-72. }\end{array}$ \\
\hline $\begin{array}{l}194.8 \text { Approval } \\
\text { process for Waste } \\
\text { Generator Sites for } \\
\text { Disposal }\end{array}$ & $\begin{array}{l}\text { Modified Visual } \\
\text { Examination (VE) } \\
\text { Process for CCP at } \\
\text { INL }\end{array}$ & $\begin{array}{l}\text { Letter from EPA to DOE (January 25, 2007). Results of the EPA evaluation of a modified } \\
\text { Visual Examination process that the CCP used to characterize RH TRU waste at INL. } \\
\text { Docket A-98-49, II-A4-75. }\end{array}$ \\
\hline $\begin{array}{l}194.8 \text { Approval } \\
\text { process for Waste } \\
\text { Generator Sites for } \\
\text { Disposal }\end{array}$ & $\begin{array}{l}\text { Approval for CCP } \\
\text { Real-Time } \\
\text { Radiography (RTR) at } \\
\text { INL }\end{array}$ & $\begin{array}{l}\text { Letter from EPA to DOE (February 12, 2007) stating that the baseline inspection previously } \\
\text { performed at INL did not include the RTR process, a follow-up inspection reviewed that } \\
\text { process and approval was given by EPA. Docket A-98-49, II-A4-80. }\end{array}$ \\
\hline $\begin{array}{l}194.8 \text { Approval } \\
\text { process for Waste } \\
\text { Generator Sites for } \\
\text { Disposal }\end{array}$ & WWIS & $\begin{array}{l}\text { Letter from EPA to DOE (February 21, 2007) giving approval to an amendment to the Tier } 1 \\
\text { change to INL's CCP amendment for RH debris waste. (Docket A-98-49, II-A4-80). EPA } \\
\text { has designated these changes as Tier } 1 \text { and } 2 \text { for the input of characterization data into the } \\
\text { WWIS at the generator sites. ( } 40 \text { CFR } 194.8 \text { (b)(iii)) }\end{array}$ \\
\hline $\begin{array}{l}194.8 \text { Approval } \\
\text { process for Waste } \\
\text { Generator Sites for } \\
\text { Disposal }\end{array}$ & $\begin{array}{l}\text { Approval process for } \\
\text { Waste Generator Sites } \\
\text { for Disposal }\end{array}$ & $\begin{array}{l}\text { Letter from EPA to DOE (February } 21,2007 \text { ) stating that after review of additional } \\
\text { information requested, the EPA approved the Tier } 2 \text { changes CCP instituted in the } 3^{\text {rd }} \text { and } \\
4^{\text {th }} \text { quarters of } 2006 \text { at SRS and INL. }\end{array}$ \\
\hline $\begin{array}{l}194.8 \text { Approval } \\
\text { process for Waste } \\
\text { Generator Sites for } \\
\text { Disposal }\end{array}$ & $\begin{array}{l}\text { Concurrence on Draft } \\
\text { Recertification for CCP } \\
\text { at SRS }\end{array}$ & $\begin{array}{l}\text { Letter from EPA to DOE (April 10, 2007). EPA concurs that the waste characterization } \\
\text { equipment, procedures and waste streams encompassed in DOE's draft recertification letter } \\
\text { comport with all of EPA's existing approvals for contact handled (CH) waste at Savannah } \\
\text { River Site (SRS)-CCP. }\end{array}$ \\
\hline $\begin{array}{l}194.8 \text { Approval } \\
\text { process for Waste } \\
\text { Generator Sites for } \\
\text { Disposal }\end{array}$ & $\begin{array}{l}\text { Amendment to DOE } \\
\text { Request to Add } \\
\text { SuperHENC Tier } 1 \\
\text { Change }\end{array}$ & $\begin{array}{l}\text { Letter from EPA to DOE (April 18, 2007). The EPA concurs that the waste characterization } \\
\text { equipment, procedures and waste streams encompassed in DOE's draft amended } \\
\text { certification letter comport with all of EPA's existing approvals for CH and RH waste at INL- } \\
\text { CCP. The EPA approved Super High Efficiency Neutron Counter as a Tier } 1 \text { change. }\end{array}$ \\
\hline
\end{tabular}


Table 1: Changes in WIPP Conditions or Activities Reportable under Title 40 CFR Section 194.4(b)(4) July 1, 2006, through June 30, 2007

\begin{tabular}{|c|c|c|}
\hline $\begin{array}{l}\text { Certification } \\
\text { Criteria }\end{array}$ & $\begin{array}{l}\text { Implementing } \\
\text { Document or } \\
\text { Activity that } \\
\text { Changed }\end{array}$ & $\begin{array}{l}\text { Description of the Change and DOE Assessment of the Impact of the } \\
\text { Change }\end{array}$ \\
\hline $\begin{array}{l}194.8 \text { Approval } \\
\text { process for Waste } \\
\text { Generator Sites for } \\
\text { Disposal }\end{array}$ & $\begin{array}{l}\text { First Quarter } 2007 \text { Tier } \\
\text { Report }\end{array}$ & $\begin{array}{l}\text { Letter from DOE to EPA (April 19, 2007) with responses to EPA questions regarding the } \\
\text { First Quarter } 2007 \text { Tier Report. }\end{array}$ \\
\hline $\begin{array}{l}194.8 \text { Approval } \\
\text { process for Waste } \\
\text { Generator Sites for } \\
\text { Disposal }\end{array}$ & $\begin{array}{l}\text { Inspection of the QA } \\
\text { Program of the CCP at } \\
\text { LANL }\end{array}$ & $\begin{array}{l}\text { On April 24-27, } 2007 \text { the EPA inspected the quality assurance (QA) program of the CCP at } \\
\text { the Los Alamos National Laboratory (LANL). EPA found no non-conformance with the } \\
\text { LANL CCP QA program and provided the results via letter on June 12, 2007. Docket No: } \\
\text { A-98-49, II-A1-94. }\end{array}$ \\
\hline $\begin{array}{l}194.8 \text { Approval } \\
\text { process for Waste } \\
\text { Generator Sites for } \\
\text { Disposal }\end{array}$ & $\begin{array}{l}\text { Approval of Tier } 2 \\
\text { Changes at SRS, INL } \\
\text { and AMWTP }\end{array}$ & $\begin{array}{l}\text { Letter from EPA to DOE (April 30, 2007) determining that the Tier } 2 \text { changes to the CH TRU } \\
\text { waste characterization program that CCP implemented at INL and SRS and the AMWTP } \\
\text { during the first quarter of Fiscal Year } 2007 \text { are appropriate and are within the parameters of } \\
\text { the baseline approvals for those sites. }\end{array}$ \\
\hline $\begin{array}{l}194.8 \text { Approval } \\
\text { process for Waste } \\
\text { Generator Sites for } \\
\text { Disposal }\end{array}$ & $\begin{array}{l}\text { Tier } 1 \text { Change } \\
\text { Proposal }\end{array}$ & $\begin{array}{l}\text { Letter from DOE to EPA (May } 3,2007 \text { ) requesting the EPA to approve a change for the } \\
\text { CCP program at SRS. EPA has identified the change as a Tier } 1 \text { level change to approve } \\
\text { an RTR unit. }\end{array}$ \\
\hline $\begin{array}{l}194.8 \text { Approval } \\
\text { process for Waste } \\
\text { Generator Sites for } \\
\text { Disposal }\end{array}$ & $\begin{array}{l}\text { Notification of Tier } 2 \\
\text { Changes }\end{array}$ & $\begin{array}{l}\text { Letter from DOE to EPA (May 3,2007) reporting changes in specific characterization and } \\
\text { certification activities for the AMWTP and CCP at INL and SRS as based upon EPA's } \\
\text { baseline inspection of ANL. }\end{array}$ \\
\hline $\begin{array}{l}194.8 \text { Approval } \\
\text { process for Waste } \\
\text { Generator Sites for } \\
\text { Disposal }\end{array}$ & AMWTP Surveillance & $\begin{array}{l}\text { Letter from DOE to EPA (May 16, 2007) requesting EPA's review and concurrence of the } \\
\text { draft expansion certification letter for the AMWTP surveillance S-07-21. }\end{array}$ \\
\hline $\begin{array}{l}194.8 \text { Approval } \\
\text { process for Waste } \\
\text { Generator Sites for } \\
\text { Disposal }\end{array}$ & $\begin{array}{l}\text { Draft Certification of } \\
\text { CEMRC CCP }\end{array}$ & $\begin{array}{l}\text { Letter from DOE to EPA (May 29, 2007) requesting EPA review and concurrence of the } \\
\text { CCP TRU waste laboratory analysis program at the Carlsbad Environmental Monitoring and } \\
\text { Research Center (CEMRC). }\end{array}$ \\
\hline
\end{tabular}


Table 1: Changes in WIPP Conditions or Activities Reportable under Title 40 CFR Section 194.4(b)(4) July 1, 2006, through June 30, 2007

\begin{tabular}{|c|c|c|}
\hline $\begin{array}{l}\text { Certification } \\
\text { Criteria }\end{array}$ & $\begin{array}{l}\text { Implementing } \\
\text { Document or } \\
\text { Activity that } \\
\text { Changed }\end{array}$ & $\begin{array}{c}\text { Description of the Change and DOE Assessment of the Impact of the } \\
\text { Change }\end{array}$ \\
\hline $\begin{array}{l}194.8 \text { Approval } \\
\text { process for Waste } \\
\text { Generator Sites for } \\
\text { Disposal }\end{array}$ & $\begin{array}{l}\text { Audit of INL CCP QA } \\
\text { Program }\end{array}$ & $\begin{array}{l}\text { Letter from EPA to DOE (June 12, 2007) providing the results of the EPA inspection of the } \\
\text { INL CCP QA program. The EPA found no non-conformance with the INL CCP QA program. }\end{array}$ \\
\hline $\begin{array}{l}194.8 \text { Approval } \\
\text { process for Waste } \\
\text { Generator Sites for } \\
\text { Disposal }\end{array}$ & $\begin{array}{l}\text { WWIS } \\
\text { Proposed Tier } 1 \\
\text { Change at ANL }\end{array}$ & $\begin{array}{l}\text { Letter from DOE to EPA (June } 20,2007 \text { ) requesting approval of changes to the CCP waste } \\
\text { characterization program at ANL. }\end{array}$ \\
\hline $\begin{array}{l}\text { 194.14(b) Design of } \\
\text { the Disposal System }\end{array}$ & $\begin{array}{l}\text { Status of Experiments } \\
\text { in the WIPP } \\
\text { Underground }\end{array}$ & $\begin{array}{l}\text { SEGA and MEGA } \\
\text { Collaborating scientists operate their detector, which required frequent exchanges of bottles } \\
\text { filled with liquid nitrogen to cool the apparatus. The experimenters also began preparations } \\
\text { for starting electroforming, anticipated by late-2007. } \\
\text { EXO } \\
\text { Several pallets of lead shielding for the experiment were received and stored underground. } \\
\text { Experimental modules continued to be assembled and tested in California. Planning and } \\
\text { preparations continued for transportation and emplacement of the modules in the WIPP } \\
\text { underground, anticipated in late } 2007 \text { or early } 2008 \text {. }\end{array}$ \\
\hline $\begin{array}{l}194.15 \text { Content of } \\
\text { Compliance } \\
\text { Recertification } \\
\text { Applications }\end{array}$ & Annotated Outline & $\begin{array}{l}\text { Letter from DOE to EPA (March 5, 2007) transmitting the Certification Reapplication (CRA)- } \\
2009 \text { Annotated Outline for comment. }\end{array}$ \\
\hline $\begin{array}{l}\text { 194.15 Content of } \\
\text { Compliance } \\
\text { Recertification } \\
\text { Applications }\end{array}$ & $\begin{array}{l}\text { Proposed Structure for } \\
\text { the } 2009 \text { Compliance } \\
\text { Recertification } \\
\text { Application }\end{array}$ & $\begin{array}{l}\text { Letter from DOE to EPA (June 11, 2007) describing and providing an example section of the } \\
\text { proposed structure for the } 2009 \text { Compliance Recertification Application for comment. }\end{array}$ \\
\hline
\end{tabular}


Table 1: Changes in WIPP Conditions or Activities Reportable under Title 40 CFR Section 194.4(b)(4) July 1, 2006, through June 30, 2007

\begin{tabular}{|c|c|c|}
\hline $\begin{array}{l}\text { Certification } \\
\text { Criteria }\end{array}$ & $\begin{array}{l}\text { Implementing } \\
\text { Document or } \\
\text { Activity that } \\
\text { Chanqed }\end{array}$ & $\begin{array}{c}\text { Description of the Change and DOE Assessment of the Impact of the } \\
\text { Change }\end{array}$ \\
\hline 194.21 Inspections & $\begin{array}{l}\text { Docket Follow-up } \\
\text { Inspection }\end{array}$ & $\begin{array}{l}\text { EPA-HQ-OAR-2006-0881-0002 EPA Docket A-98-49, II-A4-69, August 9, } 2006 \text { and } \\
\text { August 29, 2006. The EPA conducted Baseline Inspection No. EPA-INL-CCP-RH-6.06-8 of } \\
\text { the CCP WC program for RH TRU waste at the DOE INL. EPA conducted a baseline } \\
\text { inspection of the site's program to characterize RH TRU wastes proposed for disposal in the } \\
\text { WIPP. } \\
\text { - Follow-up inspection on August 9, } 2006 \text { at DOE's Carlsbad Area Field Office for } \\
\text { the purpose of assessing mass spectrometry data used to support one element } \\
\text { of the INL RH WC program. } \\
\text { - Follow-up inspection at DOE on August 29, 2006, for the purpose of resolving } \\
\text { open issues from the previous two inspections. }\end{array}$ \\
\hline 194.21 Inspections & Baseline Inspection & $\begin{array}{l}\text { EPA Baseline Inspection No. EPA-INL-CCP-RH-6.06-8 comment period closed September } \\
\text { 14, 2006. The EPA conducted Baseline Inspection No. EPA-INL-CCP-RH-6.06-8 of the } \\
\text { CCP WC program for RH TRU waste at the DOE INL. }\end{array}$ \\
\hline 194.21 Inspections & Baseline Inspection & $\begin{array}{l}\text { EPA-HQ-OAR-2006-0881-0003 Docket A-98-49, II-A4-70 Waste Characterization } \\
\text { Inspection report, September 12-14, 2006. EPA Baseline Inspection No. EPA-ANL-CCP- } \\
\text { RH-9.06-8. The EPA conducted Baseline Inspection No. EPA-ANL-CCP-RH-9.06-8 of the } \\
\text { CCP WC program for RH TRU waste at the DOE's ANL site. EPA conducted a baseline } \\
\text { inspection of the CCP's program to characterize RH TRU wastes proposed for disposal in } \\
\text { the WIPP. }\end{array}$ \\
\hline 194.21 Inspections & Baseline Inspection & $\begin{array}{l}\text { EPA-HQ-OAR-2006-0597-0002 EPA Proposed Baseline Inspection No. EPA-AMWTP- } \\
03.06-8 \text { of the AMWTP facility at INL. EPA-HQ-OAR-2006-0006. Supporting and related } \\
\text { materials for EPA-AMWTP-03.06-08. EPA-HQ-OAR-2006-0005. Letter of 11/09/2006 to } \\
\text { DOE for final approval. }\end{array}$ \\
\hline 194.21 Inspections & Baseline Inspection & $\begin{array}{l}\text { Letter from EPA to DOE (January 12, 2007) describing the results of the EPA baseline } \\
\text { inspection of the RH TRU waste characterization program implemented by CCP at INL. } \\
\text { Inspection number EPA-INL-RH-CCP-06.06-08. Docket number A-98-49, II-A4-72. }\end{array}$ \\
\hline 194.21 Inspections & Baseline Inspection & $\begin{array}{l}\text { Letter from EPA to DOE (January } 16,2007 \text { ) describing the results of the EPA baseline } \\
\text { inspection of the RH TRU waste characterization program implemented by CCP at ANL. } \\
\text { Inspection number EPA-ANL-CCP-RH-09.06-08. Docket number A-98-49, II-A4-73. }\end{array}$ \\
\hline
\end{tabular}


Table 1: Changes in WIPP Conditions or Activities Reportable under Title 40 CFR Section 194.4(b)(4) July 1, 2006, through June 30, 2007

\begin{tabular}{|c|c|c|}
\hline $\begin{array}{l}\text { Certification } \\
\text { Criteria }\end{array}$ & $\begin{array}{l}\text { Implementing } \\
\text { Document or } \\
\text { Activity that } \\
\text { Changed }\end{array}$ & $\begin{array}{c}\text { Description of the Change and DOE Assessment of the Impact of the } \\
\text { Change }\end{array}$ \\
\hline 194.21 Inspections & RH Waste Disposal & $\begin{array}{l}\text { Letter from EPA to DOE (February 8, 2007) with results of EPA's inspection at WIPP for } \\
\text { approval to manage, store and emplace RH waste at the WIPP. Approval was given. EPA } \\
\text { docket A-98-49, II-B3-101. }\end{array}$ \\
\hline 194.21 Inspections & Follow-up Inspection & $\begin{array}{l}\text { Letter from EPA to DOE (February 8, 2007) transmitting the scope of the EPA's follow-up } \\
\text { inspection of the CCP at LANL. }\end{array}$ \\
\hline 194.21 Inspections & Baseline Inspection & $\begin{array}{l}\text { Letter from EPA to DOE (April 17, 2007) transmitting the scope of the baseline inspection } \\
\text { (EPA-HAN-06.07-8) of the Hanford Site in Richland, WA. }\end{array}$ \\
\hline 194.21 Inspections & Baseline Inspection & $\begin{array}{l}\text { Letter from DOE to EPA (May 3, 2007) pertaining to submittal of Hanford documents for the } \\
\text { EPA Docket. Recertification Audit A-07-11 and A-07-10. }\end{array}$ \\
\hline 194.21 Inspections & Baseline Inspection & $\begin{array}{l}\text { Letter from EPA to DOE (May 18, 2007) responding to DOE's request for concurrence on } \\
\text { the DOE draft expansion certification letter authorizing the AMWTP to perform manual drum } \\
\text { coring of TRU CH, solid and soil/gravel waste. The EPA determined that concurrence with } \\
\text { the draft expansion certification letter is not necessary since it will not alter the contents of } \\
\text { EPA's baseline approval (A-98-49, II-A4-66) or EPA's concurrence of February } 22,2007 \text {. }\end{array}$ \\
\hline 194.21 Inspections & Baseline Inspection & $\begin{array}{l}\text { Letter from DOE to EPA (May 18, 2007) with comments pertaining to LANL-CCP-05.06-8 } \\
\text { EPA docket EPA-HQ-OAR-2007-0326. }\end{array}$ \\
\hline 194.21 Inspections & Baseline Inspection & $\begin{array}{l}\text { Letter from DOE to EPA (June 7, 2007) responding to concerns (LANL-CCP-RH-AK-07- } \\
\text { O01, LANL-CCP-RH-RC-07-002) raised during the EPA baseline inspection of the CCP at } \\
\text { LANL (EPA-LANL-RH-CCP-05.07-8) }\end{array}$ \\
\hline 194.21 Inspections & Baseline Inspection & $\begin{array}{l}\text { Letter from EPA to DOE (June 20, 2007) transmitting the scope of the EPA baseline } \\
\text { inspection (No. EPA-SRS-CCP-RH. 07.07-8) of the CCP at SRS. }\end{array}$ \\
\hline $\begin{array}{l}\text { 194.22(a) Quality } \\
\text { Assurance }\end{array}$ & $\begin{array}{l}\text { Table 2: Management } \\
\text { and Operating } \\
\text { Contractor Procedure } \\
\text { Revisions } \\
\text { Table 4: Scientific } \\
\text { Advisor Performance } \\
\text { Assessment Software } \\
\text { and Hardware } \\
\text { Changes }\end{array}$ & $\begin{array}{l}\text { The changes to Washington TRU Solutions LLC (WTS) plans and procedures listed in } \\
\text { Table } 2 \text { were deemed minor changes and improvements to the program during this } \\
\text { reporting period. } \\
\text { The changes to Sandia National Laboratories' (SNL) program documents are listed in Table } \\
4 \text { were deemed minor changes and improvements to the program during this reporting } \\
\text { period. }\end{array}$ \\
\hline
\end{tabular}


Table 1: Changes in WIPP Conditions or Activities Reportable under Title 40 CFR Section 194.4(b)(4) July 1, 2006, through June 30, 2007

\begin{tabular}{|c|c|c|}
\hline $\begin{array}{l}\text { Certification } \\
\text { Criteria }\end{array}$ & $\begin{array}{l}\text { Implementing } \\
\text { Document or } \\
\text { Activity that } \\
\text { Changed }\end{array}$ & $\begin{array}{c}\text { Description of the Change and DOE Assessment of the Impact of the } \\
\text { Change }\end{array}$ \\
\hline $\begin{array}{l}\text { 194.22(a) Quality } \\
\text { Assurance }\end{array}$ & $\begin{array}{l}\text { Inspection of DOE } \\
\text { Audit of SRS QA for } \\
\text { CCP }\end{array}$ & $\begin{array}{l}\text { Letter from EPA to DOE (February 22, 2007) had no findings pertaining to the EPA's review } \\
\text { of DOE's audit at SRS of the QA program for CCP. Docket A-98-49, II-A1-89. }\end{array}$ \\
\hline $\begin{array}{l}\text { 194.22(a) Quality } \\
\text { Assurance }\end{array}$ & $\begin{array}{l}\text { Audit of DOE QA } \\
\text { Program }\end{array}$ & $\begin{array}{l}\text { Letter from EPA to DOE (February 22, 2007) stating that EPA found that the QA program } \\
\text { continues to be properly established and implemented. Docket A-98-49, II- A1-90. }\end{array}$ \\
\hline $\begin{array}{l}\text { 194.22(a) Quality } \\
\text { Assurance }\end{array}$ & $\begin{array}{l}\text { Inspection of WTS QA } \\
\text { Program }\end{array}$ & $\begin{array}{l}\text { Letter from EPA to DOE (April } 25,2007) \text { showing that WTS has properly maintained its QA } \\
\text { program since the previous audit of the activities selected for EPA's audit sample. Docket } \\
\text { No: A-98-49, II-A1-92. }\end{array}$ \\
\hline $\begin{array}{l}\text { 194.22(a) Quality } \\
\text { Assurance }\end{array}$ & Change in CCP Audits & $\begin{array}{l}\text { Letter from DOE to EPA (June 8, 2007) informing the EPA that there will be a change in the } \\
\text { approach to the DOE QA audits of the CCP. }\end{array}$ \\
\hline $\begin{array}{l}\text { 194.22(a) Quality } \\
\text { Assurance }\end{array}$ & $\begin{array}{l}\text { EPA Inspection of } \\
\text { DOE Audit of CCP QA } \\
\text { at INL }\end{array}$ & $\begin{array}{l}\text { Letter from EPA to DOE (June 12, 2007) finding no non-conformance with the INL CCP QA } \\
\text { program. }\end{array}$ \\
\hline $\begin{array}{l}\text { 194.22(a) Quality } \\
\text { Assurance }\end{array}$ & $\begin{array}{l}\text { Submittal of CCP } \\
\text { Documents for Docket }\end{array}$ & $\begin{array}{l}\text { Letter from DOE to EPA (June 14, 2007) for the submittal of CCP documents, DOE Audit A- } \\
07-24 \text {, for the Battelle Columbus RH waste at SRS to be included in the EPA docket for the } \\
\text { baseline inspection. }\end{array}$ \\
\hline $\begin{array}{l}194.23 \text { Models and } \\
\text { Computer Codes }\end{array}$ & $\begin{array}{l}\text { Table 4: Scientific } \\
\text { Advisor Performance } \\
\text { Assessment Software } \\
\text { and Hardware } \\
\text { Changes }\end{array}$ & $\begin{array}{l}\text { The changes to PA software and hardware have been compiled and are located in Table } 4 \\
\text { and were deemed minor changes and improvements to the program during this reporting } \\
\text { period. }\end{array}$ \\
\hline $\begin{array}{l}\text { 194.24(c) Waste } \\
\text { Characterization }\end{array}$ & $\begin{array}{l}\text { CH-WAC, Contact } \\
\text { Handled Waste } \\
\text { Acceptance Criteria }\end{array}$ & $\begin{array}{l}\text { Letter from EPA to DOE (February } 28,2007 \text { ) responding to DOE's request for approval of a } \\
\text { Super HENC, Non-Destructive Analysis (NDA) system for CH TRU waste used by CCP at } \\
\text { INL. Approval was given. Docket: A-98-49, II-A4-86. }\end{array}$ \\
\hline $\begin{array}{l}\text { 194.24(c) Waste } \\
\text { Characterization }\end{array}$ & $\begin{array}{l}\text { RH-WAC, Contact } \\
\text { Handled Waste } \\
\text { Acceptance Criteria }\end{array}$ & $\begin{array}{l}\text { Letter from EPA to DOE (August } 3,2006 \text { ). After review of the Waste Acceptance Criteria } \\
\text { (WAC) Revision 5.0, the EPA expectations are that each RH TRU waste site will develop its } \\
\text { waste characterization plans based on the DOE's RH TRU Waste Characterization Program } \\
\text { Implementation Plan (WCPIP). }\end{array}$ \\
\hline $\begin{array}{l}\text { 194.24(c) Waste } \\
\text { Characterization }\end{array}$ & $\begin{array}{l}\text { RH-WAC, Contact } \\
\text { Handled Waste } \\
\text { Acceptance Criteria }\end{array}$ & $\begin{array}{l}\text { Letter from EPA to DOE (January } 17,2007 \text { ) responding to DOE request for approval of } \\
\text { WIPP Waste Information System (WWIS) for tracking of RH waste characterization by CCP } \\
\text { at INL and ANL. Docket number A-98-49, II- A4- } 74 \text {. }\end{array}$ \\
\hline
\end{tabular}


Table 1: Changes in WIPP Conditions or Activities Reportable under Title 40 CFR Section 194.4(b)(4) July 1, 2006, through June 30, 2007

\begin{tabular}{|c|c|c|}
\hline $\begin{array}{l}\text { Certification } \\
\text { Criteria }\end{array}$ & $\begin{array}{l}\text { Implementing } \\
\text { Document or } \\
\text { Activity that } \\
\text { Changed }\end{array}$ & $\begin{array}{c}\text { Description of the Change and DOE Assessment of the Impact of the } \\
\text { Change }\end{array}$ \\
\hline $\begin{array}{l}\text { 194.24(c) Waste } \\
\text { Characterization }\end{array}$ & $\begin{array}{l}\text { RH-WAC, Remote } \\
\text { Handled Waste } \\
\text { Acceptance Criteria }\end{array}$ & $\begin{array}{l}\text { Letter from DOE to EPA (January } 23,2007) \text { notifying the EPA of the first shipment of RH } \\
\text { waste to the WIPP. }\end{array}$ \\
\hline $\begin{array}{l}\text { 194.24(c) Waste } \\
\text { Characterization }\end{array}$ & $\begin{array}{l}\text { RH Debris Waste } \\
\text { Characterization at } \\
\text { LANL by CCP }\end{array}$ & $\begin{array}{l}\text { Letter from EPA to DOE (February 21, 2007) giving approval to begin characterization of } \\
\text { retrievably stored RH debris waste while awaiting the baseline inspection scheduled in } \\
\text { March of } 2007 \text {. }\end{array}$ \\
\hline $\begin{array}{l}\text { 194.24(c) Waste } \\
\text { Characterization }\end{array}$ & AMWTP & $\begin{array}{l}\text { Letter from EPA to DOE (January } 31,2007 \text { ) granting the authority for specific } \\
\text { characterization and certification activities for the AMWTP. }\end{array}$ \\
\hline $\begin{array}{l}\text { 194.24(c) Waste } \\
\text { Characterization } \\
\text { and Appendix A to } \\
\text { Part 194, Conditions } \\
2 \text { and } 3\end{array}$ & $\begin{array}{l}\text { Waste Generator Site - } \\
\text { Idaho National } \\
\text { Engineering and } \\
\text { Environmental } \\
\text { Laboratory (INL) }\end{array}$ & $\begin{array}{l}\text { Letter from EPA to DOE (January 17, 2007) responding to DOE's January } 16,2007 \text { request } \\
\text { for EPA's concurrence on the DOE's draft recertification to expand the certification of CCP } \\
\text { program at INL to include RH waste. Concurrence was given by EPA. }\end{array}$ \\
\hline $\begin{array}{l}\text { 194.24(c) Waste } \\
\text { Characterization } \\
\text { and Appendix A to } \\
\text { Part 194, Conditions } \\
2 \text { and } 3\end{array}$ & $\begin{array}{l}\text { Waste Generator Site - } \\
\text { Idaho National } \\
\text { Engineering and } \\
\text { Environmental } \\
\text { Laboratory (INL) }\end{array}$ & $\begin{array}{l}\text { Letter from EPA to DOE (February } 5,2007 \text { ) responding to DOE's request for EPA's } \\
\text { concurrence on the draft recertification of the CCP TRU waste characterization plan at INL } \\
\text { to include the modified Visual Examination process. EPA concurred. }\end{array}$ \\
\hline $\begin{array}{l}\text { 194.24(c) Waste } \\
\text { Characterization } \\
\text { and Appendix A to } \\
\text { Part 194, Conditions } \\
2 \text { and } 3\end{array}$ & $\begin{array}{l}\text { Waste Generator Site } \\
\text {-SRS }\end{array}$ & $\begin{array}{l}\text { Letter from DOE to EPA (March 28, 2007) for review and concurrence of the Draft } \\
\text { Recertification for CCP TRU Waste Program at the SRS A-07-01 and A-07-02. }\end{array}$ \\
\hline 194.42 Monitoring & $\begin{array}{l}\text { Table 3: Waste } \\
\text { Emplacement } \\
\text { Summary Report }\end{array}$ & $\begin{array}{l}\text { A summary of the TRU waste inventory that has been emplaced in the repository is } \\
\text { presented in Table } 3 \text { of this report. The inventory includes waste volume and radiological } \\
\text { activity (curie content) of waste that has been emplaced in the repository as of June } 30 \text {, } \\
2007 \text {. }\end{array}$ \\
\hline $\begin{array}{l}\text { 194.43 Passive } \\
\text { Institutional Controls }\end{array}$ & $\begin{array}{l}\text { Request for Schedule } \\
\text { Extension }\end{array}$ & $\begin{array}{l}\text { Letter from DOE to EPA (January 11, 2007) requesting an extension in Passive Institutional } \\
\text { Controls design and implementation schedule. }\end{array}$ \\
\hline
\end{tabular}


Table 1: Changes in WIPP Conditions or Activities Reportable under Title 40 CFR Section 194.4(b)(4) July 1, 2006, through June 30, 2007

\begin{tabular}{|l|l|l|}
\hline $\begin{array}{c}\text { Certification } \\
\text { Criteria }\end{array}$ & $\begin{array}{l}\text { Implementing } \\
\text { Document or } \\
\text { Activity that } \\
\text { Changed }\end{array}$ & $\begin{array}{l}\text { Description of the Change and DOE Assessment of the Impact of the } \\
\text { Change }\end{array}$ \\
\hline $\begin{array}{l}\text { 194.44 Engineered } \\
\text { Barriers }\end{array}$ & $\begin{array}{l}\text { Proposed Change to } \\
\text { the Design of the } \\
\text { Panel Closures }\end{array}$ & $\begin{array}{l}\text { Letter from DOE to EPA (January 11, 2007) requesting approval of proposed change to the } \\
\text { design of the Panel Closures at the WIPP. Letter from EPA to DOE (February 22, 2007) } \\
\text { approving a delay in the panel closure process, but did not approve a change in the design } \\
\text { or deferment of the design approval to the State of New Mexico. }\end{array}$ \\
\hline $\begin{array}{l}\text { 194.44 Engineered } \\
\text { Barriers }\end{array}$ & $\begin{array}{l}\text { Magnesium Oxide } \\
\text { Plan Change Request } \\
\text { Magnesium Oxide } \\
\text { Analysis }\end{array}$ & $\begin{array}{l}\text { Letter from DOE to EPA (Aprir 24, 2007) transmitted the proposed WIPP fact sheet on MgO } \\
\text { planned change request for possible public use. } \\
\text { Letter from DOE to EPA (May 18, 2007) transmitted DOE response to EPA's informal } \\
\text { request for information on the reactivity testing and analysis of MgO. } \\
\text { Letter from DOE to EPA (May 30, 2007) withdrawing the uncertainty analysis, Brush et al. } \\
\text { (2006). }\end{array}$ \\
\hline
\end{tabular}




\section{Table 2: Document Revisions}

July 1, 2006, through June 30, 2007 
Table 2: Document Revisions

\begin{tabular}{|c|c|c|}
\hline Procedure & $\begin{array}{l}\text { Rev. \& } \\
\text { Effective } \\
\text { Date }\end{array}$ & $\begin{array}{c}\text { Description of Changes from July 1, 2006, through } \\
\text { June } 30,2007\end{array}$ \\
\hline $\begin{array}{l}\text { Washington TRU } \\
\text { Solutions (WTS) } \\
\text { WP 02-EC3002 } \\
\end{array}$ & $\begin{array}{l}\text { Rev.\#2, } \\
07 / 20 / 06\end{array}$ & $\begin{array}{l}\text { Delaware Basin Drilling Upgrade Process. The procedure was } \\
\text { revised to allow the collection of drilling data for wells in the Delaware } \\
\text { Basin in an electronic format rather than a paper copy. }\end{array}$ \\
\hline WP 05-WH1036 & $\begin{array}{l}\text { Rev. \#5, } \\
07 / 13 / 06\end{array}$ & $\begin{array}{l}\text { Site-Derived Mixed Waste Handling. Updated equipment and } \\
\text { precautions and limitations sections. }\end{array}$ \\
\hline WP 08-NT.01 & $\begin{array}{l}\text { Rev. \#13, } \\
\text { 07/31/06 }\end{array}$ & $\begin{array}{l}\text { WIPP Waste Information System Program and Data Management } \\
\text { Plan. Updated protocols and data collection process. }\end{array}$ \\
\hline WP 08-NT.06 & $\begin{array}{l}\text { Rev. \#4, } \\
\text { 09/21/06 }\end{array}$ & $\begin{array}{l}\text { WIPP Waste Information System Software Requirements } \\
\text { Specification. Updated WWIS software requirements. }\end{array}$ \\
\hline WP 08-NT.07 & $\begin{array}{l}\text { Rev. \#4, } \\
\text { 09/21/06 }\end{array}$ & $\begin{array}{l}\text { WWIS Software Design Description. This revision is a total rewrite to } \\
\text { change the procedure from a detailed step by step guide on the } \\
\text { WWIS Software Design to a procedure that only provides a top-level } \\
\text { summary of information about software design. }\end{array}$ \\
\hline WP 08-NT3020 & $\begin{array}{l}\text { Rev. \#12, } \\
\text { 09/05/06 }\end{array}$ & $\begin{array}{l}\text { TRU Waste Receipt. Updated instructions for receipt of mixed or non- } \\
\text { mixed TRU waste shipments at the WIPP and added a new } \\
\text { attachment with a discrepancy checklist. }\end{array}$ \\
\hline WP $12-9$ & $\begin{array}{l}\text { Rev. \#24, } \\
07 / 17 / 06\end{array}$ & $\begin{array}{l}\text { WIPP Emergency Management Program. Updated emergency } \\
\text { analysis for response to emergency situations at the WIPP. }\end{array}$ \\
\hline WP 12-ER4903 & $\begin{array}{l}\text { Rev. \#11, } \\
\text { 08/01/06 }\end{array}$ & $\begin{array}{l}\text { Radiological Event Response. Addition of remote-handled (RH) } \\
\text { waste receipt process. }\end{array}$ \\
\hline WP 02-EM1012 & $\begin{array}{l}\text { Rev. \#8, } \\
11 / 13 / 2006\end{array}$ & $\begin{array}{l}\text { Airborne Particulate Sampling. Added sampling locations to } \\
\text { attachment } 2 .\end{array}$ \\
\hline WP 05-WH.01 & $\begin{array}{l}\text { Rev. \# 2, } \\
\text { 10/05/2006 }\end{array}$ & $\begin{array}{l}\text { WIPP Waste Handling Operations WWIS User's Manual. Updated } \\
\text { Attachment } 1 \text { "Special Requirements for Additional MgO". }\end{array}$ \\
\hline WP 05-WH1101 & $\begin{array}{l}\text { Rev. \# 9, } \\
11 / 27 / 2006\end{array}$ & $\begin{array}{l}\text { Surface Transuranic Mixed Waste Handling Area Inspections. Added } \\
\text { surface storage area capacities. }\end{array}$ \\
\hline WP 05-WH1810 & $\begin{array}{l}\text { Rev. \# 10, } \\
11 / 27 / 2006\end{array}$ & $\begin{array}{l}\text { Underground Transuranic Mixed Waste Disposal Area Inspections. } \\
\text { Added a requirement to Attachment } 2 \text { - Preoperational Waste } \\
\text { Handling Mode Checklist, to complete Form EAO4AD3001-2-0, } \\
\text { Facility TSR Administrative Controls Checklist CH Waste Handling } \\
\text { Mode, for delivery to Central Monitoring Room requesting mode. }\end{array}$ \\
\hline
\end{tabular}


Table 2: Document Revisions

\begin{tabular}{|c|c|c|}
\hline Procedure & $\begin{array}{l}\text { Rev. \& } \\
\text { Effective } \\
\text { Date }\end{array}$ & $\begin{array}{l}\text { Description of Changes from July 1, 2006, through } \\
\text { June 30, } 2007\end{array}$ \\
\hline WP 08-NT.01 & $\begin{array}{l}\text { Rev. \# 14, } \\
10 / 18 / 2006\end{array}$ & $\begin{array}{l}\text { WWIS Program and Data Management Plan. Section } 3.2 \text { Summary } \\
\text { of Hazardous Waste Facility Permit Requirements, was expanded to } \\
\text { better identify how the WWIS tracks information required by the } \\
\text { Waste Analysis Plan. Identified the public access link to the WWIS. }\end{array}$ \\
\hline WP 08-NT.03 & $\begin{array}{l}\text { Rev. \# 8, } \\
10 / 18 / 2006\end{array}$ & $\begin{array}{l}\text { Waste Stream Profile Form Review and Approval Program. An } \\
\text { Acronyms and Abbreviations list was added. Section 3.0, Conducting } \\
\text { the Waste Stream Profile Form, was deleted along with two figures } \\
\text { that were no longer required. }\end{array}$ \\
\hline WP 08-NT3020 & $\begin{array}{l}\text { Rev. \# 13, } \\
11 / 16 / 2006\end{array}$ & $\begin{array}{l}\text { TRU Waste Receipt. Added information and attachment pertaining to } \\
\text { RH waste. }\end{array}$ \\
\hline WP 12-ER4902 & $\begin{array}{l}\text { Rev. \# 10, } \\
12 / 04 / 2006\end{array}$ & $\begin{array}{l}\text { Hazardous Material Spill and Release Response. Updated } \\
\text { Immediate and Subsequent Actions sections. }\end{array}$ \\
\hline WP 12-ER4903 & $\begin{array}{l}\text { Rev. \# 12, } \\
10 / 25 / 2006\end{array}$ & Radiological Event Response. Updated for RH process. \\
\hline WP 05-WH1710 & $\begin{array}{l}\text { Rev \# 6, } \\
01 / 05 / 2007\end{array}$ & $\begin{array}{l}\text { 72-B RH Processing. Added warnings and notes throughout } \\
\text { procedure for personnel working with } \mathrm{RH} \text { waste. }\end{array}$ \\
\hline WP 05-WH1758 & $\begin{array}{l}\text { Rev \# 3, } \\
01 / 05 / 2007\end{array}$ & $\begin{array}{l}\text { RH Waste Handling Abnormal Operations. Added notes to procedure } \\
\text { to identify steps in the procedure so "Limiting Conditions of } \\
\text { Operations (LCO) 3.3.2" may be entered. }\end{array}$ \\
\hline WP 08-NT3020 & $\begin{array}{l}\text { Rev. \# } 14 \\
02 / 14 / 2007\end{array}$ & $\begin{array}{l}\text { TRU Waste receipt. Combined the CH TRU Waste Receipt Checklist } \\
\text { and the RH TRU Waste Receipt Checklist into one checklist titled } \\
\text { TRU Waste Receipt Checklist. }\end{array}$ \\
\hline WP 02-1 & $\begin{array}{l}\text { Rev \# 7, } \\
\text { 03/09/2007 }\end{array}$ & $\begin{array}{l}\text { WIPP Groundwater Monitoring Program Plan. Added the } \\
\text { requirements of DOE Orders 450.1, Chg. 3, Environmental Protection } \\
\text { Program. }\end{array}$ \\
\hline
\end{tabular}


Table 2: Document Revisions

\begin{tabular}{|c|c|c|}
\hline Procedure & $\begin{array}{l}\text { Rev. \& } \\
\text { Effective } \\
\text { Date }\end{array}$ & $\begin{array}{c}\text { Description of Changes from July 1, 2006, through } \\
\text { June } 30,2007\end{array}$ \\
\hline WP 13-1 & $\begin{array}{l}\text { Rev \# 26, } \\
03 / 23 / 2007\end{array}$ & $\begin{array}{l}\text { Washington TRU Solutions LLC Quality Assurance Program. This } \\
\text { revision incorporates new order DOE O 226.1, Implementation of } \\
\text { Department of Energy Oversight Policy, requirements; DOE Order } \\
414.1 C \text {, Quality Assurance, changes; and DOE QAPD, revision 8, } \\
\text { changes. The revised DOE QAPD, revised QA Order, and new order } \\
\text { DOE O } 226.1 \text { are the primary drivers for this revision. The QA } \\
\text { requirements, per O } 414.1 C \text { and } 10 \text { CFR } 830 \text { Subpart A, are not } \\
\text { adversely impacted by changes made in this revision and continue to } \\
\text { be satisfied. }\end{array}$ \\
\hline WP 08-NT3020 & $\begin{array}{l}\text { Rev \#15, } \\
04 / 13 / 2007\end{array}$ & $\begin{array}{l}\text { TRU Waste Receipt. Added fissile excepted notation UN2917 } \\
\text { shipping name to Attachment } 1 .\end{array}$ \\
\hline CAO/WIPP 01-3199 & $\begin{array}{l}\text { Rev \# 3, } \\
04 / 20 / 2007\end{array}$ & $\begin{array}{l}\text { Recertification Project Plan. Update lessons learned and } \\
\text { organizational changes since issuing the 2004-CRA. }\end{array}$ \\
\hline E-I-473 & $\begin{array}{l}\text { Rev \# 0, } \\
05 / 11 / 2007\end{array}$ & $\begin{array}{l}\text { Specification for the Fabrication of RH Steel/Concrete Shield. The } \\
\text { purpose of this specification is to convey fabrication requirements and } \\
\text { testing and acceptance criteria for the RH Steel/Concrete Shield Plug, } \\
\text { unless otherwise specified on the drawings or in procurement } \\
\text { documentation. }\end{array}$ \\
\hline CAO/WIPP 02-3184 & $\begin{array}{l}\text { Rev \# 5, } \\
05 / 18 / 2007\end{array}$ & $\begin{array}{l}\text { CH Packaging Operations Manual. New revision to encompass } \\
\text { numerous procedure updates. }\end{array}$ \\
\hline WP 02-PC3002 & $\begin{array}{l}\text { Rev \# 7, } \\
05 / 18 / 2007\end{array}$ & $\begin{array}{l}\text { WIPP Hazardous Waste Facility Permit Change Request and } \\
\text { Modification Processing. New revision for updates to the Permit } \\
\text { Modification Request process. }\end{array}$ \\
\hline WP 05-WH1706 & $\begin{array}{l}\text { Rev \# 7, } \\
05 / 18 / 2007\end{array}$ & $\begin{array}{l}\text { Preparation of an Empty RH-TRU 72-B Cask for Shipment. New } \\
\text { revision. }\end{array}$ \\
\hline WP 05-WH1707 & $\begin{array}{l}\text { Rev \# 7, } \\
05 / 18 / 2007\end{array}$ & $\begin{array}{l}\text { RH-TRU 72-B Trailer Loading. New revision to update trailer loading } \\
\text { process. }\end{array}$ \\
\hline WP 05-WH1709 & $\begin{array}{l}\text { Rev \#10, } \\
05 / 18 / 2007\end{array}$ & $\begin{array}{l}\text { RH-TRU 72-B Trailer Unloading. New revision to update trailer } \\
\text { unloading process. }\end{array}$ \\
\hline WP 05-WH1710 & $\begin{array}{l}\text { Rev \# 8, } \\
05 / 18 / 2007\end{array}$ & $\begin{array}{l}\text { 72-B RH Processing. New revision for updates in } \mathrm{RH} 72-\mathrm{B} \text { handling } \\
\text { process. }\end{array}$ \\
\hline WP 05-WH1758 & $\begin{array}{l}\text { Rev \# 4, } \\
05 / 18 / 2007\end{array}$ & $\begin{array}{l}\text { RH Waste Handling Abnormal Operations. New revision adding } \\
\text { Section 21.0 Reposition 72-B Cask to Position X. }\end{array}$ \\
\hline
\end{tabular}


Table 2: Document Revisions

\begin{tabular}{|c|c|c|}
\hline Procedure & $\begin{array}{c}\text { Rev. \& } \\
\text { Effective } \\
\text { Date }\end{array}$ & $\begin{array}{l}\text { Description of Changes from July 1, 2006, through } \\
\text { June 30, } 2007\end{array}$ \\
\hline WP 08-NT.01 & $\begin{array}{l}\text { Rev } \# 16 \\
05 / 18 / 2007\end{array}$ & $\begin{array}{l}\text { WIPP Waste Information System Program and Data Management } \\
\text { Plan. Implementation of new TRAMPAC evaluation software. }\end{array}$ \\
\hline WP 02-PC.06 & $\begin{array}{l}\text { Rev \# 1, } \\
06 / 01 / 2007\end{array}$ & $\begin{array}{l}\text { Recertification Strategy and Project Execution Plan. Update lessons } \\
\text { learned and organizational changes since issuing the 2004-CRA. } \\
\text { Revised to be consistent with DOE Recertification Plan. }\end{array}$ \\
\hline WP 12-ER4902 & $\begin{array}{l}\text { Rev \#11, } \\
06 / 29 / 2007\end{array}$ & $\begin{array}{l}\text { Hazardous Material Spill and Release Response. Removal of } \\
\text { exempted small quantity spills section. }\end{array}$ \\
\hline $\begin{array}{l}\text { NP 2-1, Qualification } \\
\text { and Training }\end{array}$ & $\begin{array}{l}\text { Rev. } 9 \\
09 / 29 / 06\end{array}$ & $\begin{array}{l}\text { NP 2-1 was revised as follows: } \\
\text { - To require Initial WIPP QA Program Training only for new } \\
\text { personnel and removed requirement for Annual WIPP QA } \\
\text { Program Training. } \\
\text { - } \quad \text { Revised the External Reviewer process. } \\
\end{array}$ \\
\hline $\begin{array}{l}\text { NP 6-1, Document } \\
\text { Review Process }\end{array}$ & $\begin{array}{l}\text { Rev. } 6 \\
09 / 20 / 06\end{array}$ & $\begin{array}{l}\text { NP 6-1 was revised as follows: } \\
\text { - To align with changes implemented in other procedures. }\end{array}$ \\
\hline NP 9-1, Analyses & $\begin{array}{l}\text { Rev. 6, } \\
08 / 29 / 06\end{array}$ & $\begin{array}{l}\text { NP 9-1 was changed to interface with a change in NP 9-2, } \\
\text { Parameters, and to accommodate EPA and DOE Analysis requests. } \\
\text { Specific changes include: } \\
\text { - Changed the scope with a new Section } 2.3 \text { to include } \\
\text { EPA/DOE Analyses/Information Requests and DOE Planned } \\
\text { Change Requests. } \\
\text { - Added requirements for parameter justifications to develop a } \\
\text { table of parameters that will be attached to the parameter } \\
\text { data entry form in NP 9-2. } \\
\text { - Created a requirement for the capture of outside DOE } \\
\text { qualified data (WTS, LANL, etc.) } \\
\text { Clarified when and what a Routine Calculation could be used } \\
\text { for. }\end{array}$ \\
\hline
\end{tabular}


Table 2: Document Revisions

\begin{tabular}{|l|l|l|}
\hline \multicolumn{1}{|c|}{ Procedure } & $\begin{array}{c}\text { Rev. \& } \\
\text { Effective } \\
\text { Date }\end{array}$ & $\begin{array}{c}\text { Description of Changes from July 1, 2006, through } \\
\text { June 30, 2007 }\end{array}$ \\
\hline NP 9-2, Parameters & $\begin{array}{l}\text { Rev. 1, } \\
08 / 29 / 06\end{array}$ & $\begin{array}{l}\text { NP 9-2 was changed to accommodate a new requirement in NP 5-1 } \\
\text { for reviewing procedures every three years. The major changes } \\
\text { include: } \\
\text { Allow a table of parameter values to be attached to the Data } \\
\text { Entry Form rather than the previous one to one relationship of } \\
\text { form to parameters. } \\
\text { Eliminated the Tech review of the data entry form. The } \\
\text { technical review is part of the NP 9-1 Analysis Parameter } \\
\text { Justification process. } \\
\text { Ordered the procedure steps rather than the previous } \\
\text { narrative instructions to help the process flow. } \\
\text { Added an Analysis definition process to enhance the } \\
\text { traceability between the software and parameters used for a } \\
\text { calculation. } \\
\text { Removed the Definitions section. Definitions will be in the } \\
\text { Glossary. }\end{array}$ \\
\hline $\begin{array}{l}\text { SP 12-9, Calibration, } \\
\text { Use, and Maintenance } \\
\text { of the Perkin Elmer } \\
\text { Optima 3000 Dual } \\
\text { View (DV) ICP-AES }\end{array}$ & $\begin{array}{l}\text { Rev. 1, } \\
07 / 12 / 06\end{array}$ & $\begin{array}{l}\text { In this revision, the acceptance level of an internal standard in a high } \\
\text { concentration check standard has been revised to account for } \\
\text { interference. }\end{array}$ \\
\hline $\begin{array}{l}\text { SP 12-14, Use of pH } \\
\text { Meters and Electrodes }\end{array}$ & $\begin{array}{l}\text { Rev. 1, } \\
07 / 26 / 06\end{array}$ & $\begin{array}{l}\text { Changed Section 2.6.5 to state that the performance test will be } \\
\text { performed immediately after calibration and then again if the analysis } \\
\text { lasts more than two hours. In addition, the start and stop time of the } \\
\text { analysis must be recorded in the scientific notebook. }\end{array}$ \\
\hline
\end{tabular}


Table 2: Document Revisions

\begin{tabular}{|c|c|c|}
\hline Procedure & $\begin{array}{c}\text { Rev. \& } \\
\text { Effective } \\
\text { Date }\end{array}$ & $\begin{array}{c}\text { Description of Changes from July 1, 2006, through } \\
\text { June } 30,2007\end{array}$ \\
\hline NP 17-1, Records & $\begin{array}{l}\text { Rev. } 6 \\
12 / 22 / 06\end{array}$ & $\begin{array}{l}\text { NP 17-1 was revised as follows: } \\
\text { - Section 2.1, editorial changes. Deleted } 2^{\text {nd }} \text { bulleted item (no } \\
\text { longer a valid statement). } 4^{\text {th }} \text { paragraph, deleted } 2^{\text {nd }} \text { sentence } \\
\text { because any method is good as long as the record is } \\
\text { paginated. Also, deleted last sentence, (not needed.) } \\
\text { - Section } 2.3 .1 \text {, had to change this paragraph to reflect } \\
\text { changes on form. } \\
\text { - Section } 2.4,3^{\text {rd }} \text { paragraph, change “.... memorandum of } \\
\text { correction should..." to "... a memorandum of correction } \\
\text { will...". Changed wording to reflect program requirement. } \\
\text { - Section 3.0, deleted columns "Preparer" and "Records } \\
\text { Submitter" as suggested by DOE/DOE. } \\
\text { Form NP 17-1-1, Changes were made to reflect current } \\
\text { activities and clarification. Minor editorial changes were made } \\
\text { as well. Combined Sections I and II and deleted page } 3 .\end{array}$ \\
\hline $\begin{array}{l}\text { NP 18-1, Audits and } \\
\text { Surveillances }\end{array}$ & $\begin{array}{l}\text { Rev. 6, } \\
11 / 17 / 06\end{array}$ & $\begin{array}{l}\text { NP 18-1 was revised as follows: } \\
\text { - To meet the commitment to review NP and SP procedures on } \\
\text { a three year cycle to assure procedures remain current (DOE } \\
\text { CAR 06-010, identified in Audit A-06-05.) } \\
\text { - To address an Observation (Observation 1) identified during } \\
\text { the Internal/External QA Audit IA 05-01 on the confusion of } \\
\text { identifying "Records Preparer" and "Records Submitter" in the } \\
\text { Records Section of the procedure. This information was } \\
\text { deleted from the procedure and is not a requirement. } \\
\text { - To make the procedure more consistent with the SNL QAPD } \\
\text { in the areas of "Scheduling" and "Surveillances." } \\
\text { - To add a distribution section to the surveillance report form } \\
\text { (Form NP 18-1-4) and to make other editorial changes to the } \\
\text { procedure. }\end{array}$ \\
\hline
\end{tabular}


Table 2: Document Revisions

\begin{tabular}{|c|c|c|}
\hline Procedure & $\begin{array}{l}\text { Rev. \& } \\
\text { Effective } \\
\text { Date }\end{array}$ & $\begin{array}{l}\text { Description of Changes from July 1, 2006, through } \\
\text { June 30, } 2007\end{array}$ \\
\hline $\begin{array}{l}\text { SP 9-5, Parameter } \\
\text { Data Entry }\end{array}$ & $\begin{array}{l}\text { Rev. 1, } \\
\text { 10/04/06 }\end{array}$ & $\begin{array}{l}\text { SP 9-5 was revised as follows: } \\
\text { - To match NP 9-2, Parameters. } \\
\text { - Rearranged the order of the sections so that some duplicate } \\
\text { - } \text { steps could be eliminated. } \\
\text { - } \text { Add two appendices: } \\
\text { A) Flowchart \& Worksheet--showing graphical representation } \\
\text { of the Parameter Data Entry process, and } \\
\text { B) Hierarchical Worksheet--for recording needed record ID } \\
\text { numbers during Parameter Data Entry. }\end{array}$ \\
\hline $\begin{array}{l}\text { SP 13-2, Core } \\
\text { Sample Logging and } \\
\text { Management }\end{array}$ & $\begin{array}{l}\text { Rev. 4, } \\
\text { 12/14/06 }\end{array}$ & $\begin{array}{l}\text { SP 13-2 was revised to update the methodology for core disposal, } \\
\text { core storage requirements, and core management/tracking. The } \\
\text { terminology/formatting were also updated. }\end{array}$ \\
\hline $\begin{array}{l}\text { NP 1-1, Organization } \\
\text { and QA Program, } \\
\text { Rev. } 6 .\end{array}$ & $01 / 08 / 07$ & $\begin{array}{l}\text { NP 1-1 was revised as follows: } \\
\text { - Modified text to more closely align with the QAPD } \\
\text { requirement. } \\
\text { Removed Organizational Structure Description from the } \\
\text { records section. The organizational chart is referred to in the } \\
\text { Program Description document and is available on the SNL } \\
\text { WIPP Online Documents web site. }\end{array}$ \\
\hline $\begin{array}{l}\text { SP 9-7, WIPP Well } \\
\text { Water-Level } \\
\text { Monitoring, Rev. } 2 \text {. }\end{array}$ & 03/06/07 & $\begin{array}{l}\text { SP 9-7 was revised to reflect changes in the TROLL installation and } \\
\text { test setup procedures, which included: } \\
\text { - Modification of acceptance criteria for the pressure } \\
\text { transducer. } \\
\text { - Addition of steps to be completed if the pressure transducer is } \\
\text { outside of acceptance criteria. } \\
\text { - Addition of more detailed TROLL user-instructions } \\
\text { (Appendices A and B.) }\end{array}$ \\
\hline
\end{tabular}


Table 2: Document Revisions

\begin{tabular}{|c|c|c|}
\hline Procedure & $\begin{array}{l}\text { Rev. \& } \\
\text { Effective } \\
\text { Date }\end{array}$ & $\begin{array}{l}\text { Description of Changes from July 1, 2006, through } \\
\text { June 30, } 2007\end{array}$ \\
\hline $\begin{array}{l}\text { SP 12-5, Depth-to- } \\
\text { Water Measurement } \\
\text { Using a Solinst Brand } \\
\text { Electric Sounder, Rev. } \\
1 .\end{array}$ & $03 / 15 / 07$ & $\begin{array}{l}\text { SP 12-5 was revised as follows: } \\
\text { - Minor editorial changes were made to this procedure in order } \\
\text { to reflect the current condition under which this procedure is } \\
\text { used. }\end{array}$ \\
\hline $\begin{array}{l}\text { SP 20-4, Preparing } \\
\text { Synthetic Brines for } \\
\text { Geochemical } \\
\text { Experiments, Rev. } 1 .\end{array}$ & $01 / 18 / 07$ & $\begin{array}{l}\text { SP 20-4 was revised so that the user can make large quantities of } \\
\text { brines based on the recipes on molality scale. }\end{array}$ \\
\hline $\begin{array}{l}\text { NP 4-1, } \\
\text { Procurement } \\
\text { Revision } 8\end{array}$ & $05 / 14 / 07$ & $\begin{array}{l}\text { Changes were made to NP 4-1 for clarification, detail of the process } \\
\text { description, and editorial changes, including: } \\
\text { - No purchase of QL-1 or QL-2 items or services with personal } \\
\text { or corporate credit cards is allowed. See section 2.1.1. } \\
\text { - Addressed in more detail the use of the documenting the } \\
\text { annual evaluation of service suppliers through the period of } \\
\text { the contract. See section } 2.5 \text {. } \\
\text { - Added item identification from the Procurement Review (Form } \\
\text { NP 4-1-1, section 1) to the Receipt Inspection (Form NP 4-1- } \\
\text { 2, section 1) and included a copy of receipt documentation. } \\
\text { See section 2.5.2 for details. } \\
\text { - Made changes to Form NP 4-1-1, Procurement Review, in } \\
\text { sections } 2 \text { and } 3 \text { for clarification. } \\
\text { Deleted the "Annual" QA Training in Procurement Review } \\
\text { Form, section 3, item 1, of Appendix C. }\end{array}$ \\
\hline
\end{tabular}


Table 2: Document Revisions

\begin{tabular}{|c|c|c|}
\hline Procedure & $\begin{array}{l}\text { Rev. \& } \\
\text { Effective } \\
\text { Date }\end{array}$ & $\begin{array}{c}\text { Description of Changes from July 1, 2006, through } \\
\text { June } 30,2007\end{array}$ \\
\hline $\begin{array}{l}\text { NP 16-1, } \\
\text { Corrective Action } \\
\text { Revision } 6\end{array}$ & $06 / 19 / 07$ & $\begin{array}{l}\text { NP 16-1 was revised as follows: } \\
\text { - Removed the note on page 3, limiting the number of } \\
\text { extension requests to three (3). This information is contained } \\
\text { in the } 4^{\text {th }} \text { paragraph on page three and was redundant. } \\
\text { - } \text { Deleted redundant information on Significant Condition } \\
\text { Adverse to Quality (SCAQ) in last paragraph of section 2.2.2. } \\
\text { - } \quad \text { Added text in section } 2.3 \text { to clarify that Corrective Action } \\
\text { Requests (CARs) are not issued for ES\&H issues as follow- } \\
\text { up to Stop Work. } \\
\text { - Deleted the information on "Preparer" and "Records } \\
\text { Submitter" on page 6, in section 3.0 Records, to be consistent } \\
\text { with all procedures. } \\
\text { Deleted the term "Refresher" from page 10, Appendix D, } \\
\text { "Causal Codes", in item 5d. Annual QA Refresher Training } \\
\text { will no longer be given, only QA Training to new employees. }\end{array}$ \\
\hline $\begin{array}{l}\text { NP 20-2, } \\
\text { Scientific Notebooks } \\
\text { Revision } 7\end{array}$ & $05 / 21 / 07$ & $\begin{array}{l}\text { NP 20-2 was revised to add a requirement that logbooks that record } \\
\text { quality affecting data (either daily or prior to use) will receive a QA } \\
\text { review will occur at a minimum of every } 6 \text { months. }\end{array}$ \\
\hline $\begin{array}{l}\text { SP 17-1 } \\
\text { Records Center } \\
\text { Operations } \\
\text { Revision } 7 \\
\end{array}$ & $04 / 10 / 07$ & SP 17-1 was revised to incorporate editorial changes. \\
\hline 194.42 Monitoring & $\begin{array}{l}\text { Delaware } \\
\text { Basin } \\
\text { Monitoring } \\
\text { Annual Report } \\
\text { DOE/WIPP- } \\
\text { 99-2308 }\end{array}$ & $\begin{array}{l}\text { DOE/WIPP-99-2308, Rev. } 7 \text {, issued in September 2006. The time } \\
\text { period for which this report covers is September } 1,2005 \text {, through } \\
\text { August } 31,2006 \text {. }\end{array}$ \\
\hline
\end{tabular}


Table 2: Document Revisions

\begin{tabular}{|c|c|c|}
\hline Procedure & $\begin{array}{l}\text { Rev. \& } \\
\text { Effective } \\
\text { Date }\end{array}$ & $\begin{array}{c}\text { Description of Changes from July 1, 2006, through } \\
\text { June 30, } 2007\end{array}$ \\
\hline 194.42 Monitoring & $\begin{array}{l}\text { WIPP Site } \\
\text { Environmental } \\
\text { Report } \\
\text { Calendar } \\
\text { Year } 2005 \\
\text { DOE/WIPP } \\
2006-2225\end{array}$ & $\begin{array}{l}\text { DOE/WIPP 2006-2225, WIPP CY2005 Site Environmental Report, } \\
\text { submitted September } 2006 \text {. This report provides information and } \\
\text { data on groundwater and meteorological monitoring. }\end{array}$ \\
\hline 194.42 Monitoring & $\begin{array}{l}\text { WIPP } \\
\text { Subsidence } \\
\text { Monument } \\
\text { Leveling } \\
\text { Survey } \\
\text { DOE/WIPP- } \\
2007-2293 \\
\end{array}$ & $\begin{array}{l}\text { DOE/WIPP-2007-2293, WIPP Subsidence Monument Leveling } \\
\text { Survey, was issued in December, 2006. Subsidence information } \\
\text { obtained from surveys conducted September through December, } \\
2006 \text { is included in the report. }\end{array}$ \\
\hline INV-AP-01 & $\begin{array}{l}\text { Rev.2, } \\
10 / 23 / 2006\end{array}$ & Analysis Plan for Transuranic Waste Inventory \\
\hline INV-SP-01 & $\begin{array}{l}\text { Rev. } 4 \\
1 / 30 / 2007\end{array}$ & $\begin{array}{l}\text { Data Collection, Data Management and Control for the } \\
\text { Comprehensive Inventory }\end{array}$ \\
\hline INV-SP-02 & $\begin{array}{l}\text { Rev. } 6 \\
8 / 2 / 2007\end{array}$ & $\begin{array}{l}\text { Entry, Verification and Validation of Inventory Information in the } \\
\text { Comprehensive Inventory Database }\end{array}$ \\
\hline INV-SP-03 & $\begin{array}{l}\text { Rev. 3, } \\
10 / 23 / 2006\end{array}$ & Responding to Requests for Quality Level 1 Inventory Information \\
\hline LCO-QP6-1 & $\begin{array}{l}\text { Rev. 3, } \\
1 / 26 / 2007\end{array}$ & Controlled Document Development, Change and Revision \\
\hline LCO-QP17-1 & $\begin{array}{l}\text { Rev. 3, } \\
1 / 26 / 2007\end{array}$ & Record Management \\
\hline LCO-QP19-1 & $\begin{array}{l}\text { Rev. } 1 \\
6 / 29 / 2007\end{array}$ & Software Quality Assurance \\
\hline LCO-QPD-02 & $\begin{array}{l}\text { Rev. 2, } \\
6 / 26 / 2007\end{array}$ & LANL-CO Software Quality Assurance Plan \\
\hline LCO-QPD-05 & $\begin{array}{l}\text { Rev. } 1 \\
5 / 10 / 2007\end{array}$ & WIPP Compliance and Recertification Program Strategy Plan \\
\hline
\end{tabular}


Table 3: Waste Emplacement Summary Report

July 1, 2006, through June 30, 2007 
Table 3: Waste Emplacement Summary Report

\begin{tabular}{|c|c|c|c|c|}
\hline \multicolumn{5}{|c|}{ TRU Waste Inventory } \\
\hline & \multicolumn{2}{|c|}{$\begin{array}{l}\text { Reporting Period } \\
\text { Emplaced Container } \\
\text { Volume }\left(\mathrm{m}^{3}\right)\end{array}$} & \multicolumn{2}{|c|}{$\begin{array}{c}\text { Cumulative }{ }^{2} \text { Emplaced Container } \\
\text { Volume }\left(\mathrm{m}^{3}\right)\end{array}$} \\
\hline \multirow{2}{*}{$\begin{array}{l}\text { RH TRU } \\
\text { CH TRU }\end{array}$} & \multicolumn{2}{|c|}{12} & \multicolumn{2}{|r|}{12} \\
\hline & & & & 49,404 \\
\hline \multicolumn{5}{|c|}{ Waste Components Inventory } \\
\hline & $\begin{array}{l}\text { Reporting }^{1} \\
\text { Period }^{1} \\
\text { Emplaced } \\
\text { Mass (kg) }\end{array}$ & $\begin{array}{c}\text { Cumulative }^{2} \\
\text { Emplaced } \\
\text { Mass (kg) }\end{array}$ & $\begin{array}{c}\text { Maximum } \\
\text { Emplacement } \\
\text { Limiting } \\
\text { Value }^{3}(\mathrm{~kg})\end{array}$ & $\begin{array}{l}\text { Percent of Limiting } \\
\text { Value }^{3} \text { Emplaced }\end{array}$ \\
\hline \multirow{2}{*}{$\begin{array}{l}\text { Cellulose, } \\
\text { Plastic, } \\
\text { Rubber } \\
\text { Materials }^{4}\end{array}$} & 250,033 & $4,569,766$ & $22,000,000$ & $20.77 \%$ \\
\hline & $\begin{array}{l}\text { Reporting } \\
\text { Period }^{1} \\
\text { Emplaced } \\
\text { Mass (kg) }\end{array}$ & $\begin{array}{c}\text { Cumulative }^{2} \\
\text { Emplaced } \\
\text { Mass (kg) }\end{array}$ & $\begin{array}{c}\text { Minimum } \\
\text { Emplacement } \\
\text { Limiting } \\
\text { Value }^{3}(\mathrm{~kg})\end{array}$ & $\begin{array}{l}\text { Percent of Limiting } \\
\text { Value }^{3} \text { Emplaced }\end{array}$ \\
\hline Fe-Metals ${ }^{5}$ & 725,385 & $13,817,793$ & $20,000,000$ & $69.09 \%$ \\
\hline $\begin{array}{l}\text { Non-Fe } \\
\text { Metals }\end{array}$ & 7,659 & 301,117 & 2,000 & Minimum met \\
\hline $\begin{array}{l}\text { Residual } \\
\text { Liquids }\end{array}$ & \multicolumn{4}{|c|}{$\begin{array}{l}\text { Liquid waste is prohibited at WIPP. The total residual liquid in any } \\
\text { payload container shall not exceed one percent by volume of that } \\
\text { payload container. }\end{array}$} \\
\hline
\end{tabular}

\begin{tabular}{|c|c|c|c|c|}
\hline \multicolumn{5}{|c|}{ Emplaced Radiological Activity Inventory (curies) } \\
\hline Radionuclide & $\begin{array}{c}\text { Cumulative } \\
\text { Activity in } \\
\text { FY } \\
\text { 2005/2006 } \\
\text { Annual } \\
\text { Change } \\
\text { Report }\end{array}$ & $\begin{array}{c}\text { CH } \\
\text { Reporting } \\
\text { Period } \\
\text { Activity }\end{array}$ & $\begin{array}{c}\text { RH } \\
\text { Reporting } \\
\text { Period } \\
\text { Activity }\end{array}$ & $\begin{array}{c}\text { Total Activity as of } \\
\text { June 30, 2007 }\end{array}$ \\
\hline${ }^{241} \mathbf{A m}$ & $1.71 \mathrm{E}+05$ & $1.17 \mathrm{E}+04$ & $4.251 \mathrm{E}+00$ & $1.827 \mathrm{E}+05$ \\
\hline${ }^{137} \mathbf{C s}$ & $1.40 \mathrm{E}+00$ & $9.52 \mathrm{E}+01$ & $9.536 \mathrm{E}+01$ & $9.662 \mathrm{E}+01$ \\
\hline${ }^{238} \mathbf{P u}$ & $5.29 \mathrm{E}+04$ & $4.69 \mathrm{E}+04$ & $2.419 \mathrm{E}+00$ & $9.978 \mathrm{E}+04$ \\
\hline${ }^{239} \mathbf{P u}$ & $2.52 \mathrm{E}+05$ & $1.32 \mathrm{E}+04$ & $8.760 \mathrm{E}+00$ & $2.652 \mathrm{E}+05$ \\
\hline${ }^{240} \mathbf{P u}$ & $6.05 \mathrm{E}+04$ & $3.66 \mathrm{E}+03$ & $4.611 \mathrm{E}+00$ & $6.416 \mathrm{E}+04$ \\
\hline${ }^{242} \mathbf{P u}$ & $8.63 \mathrm{E}+00$ & $1.03 \mathrm{E}+00$ & $1.454 \mathrm{E}-03$ & $9.660 \mathrm{E}+00$ \\
\hline${ }^{90} \mathbf{S r}$ & $1.56 \mathrm{E}+00$ & $7.21 \mathrm{E}+01$ & $7.060 \mathrm{E}+01$ & $7.365 \mathrm{E}+01$ \\
\hline${ }^{233} \mathbf{U}$ & $1.85 \mathrm{E}+00$ & $0.81 \mathrm{E}+00$ & $1.570 \mathrm{E}-02$ & $2.656 \mathrm{E}+00$ \\
\hline${ }^{234} \mathbf{U}$ & $9.69 \mathrm{E}+00$ & $7.16 \mathrm{E}+00$ & $2.841 \mathrm{E}-02$ & $1.685 \mathrm{E}+01$ \\
\hline${ }^{238} \mathbf{U}$ & $1.02 \mathrm{E}+01$ & $0.03 \mathrm{E}+01$ & $1.684 \mathrm{E}-04$ & $1.053 \mathrm{E}+01$ \\
\hline Total & $\mathbf{5 . 3 6 E + 0 5}$ & $\mathbf{7 . 6 1 E + 0 4}$ & $\mathbf{1 . 8 6 0 \mathrm { E } + 0 2}$ & $\mathbf{6 . 1 2 1 \mathrm { E } + 0 5}$ \\
\hline
\end{tabular}

\footnotetext{
1. Reporting Period includes emplacement that occurred between July 1, 2006, and June 30, 2007

2. Cumulative period includes emplacement from the beginning until June 30,2007

3. Limiting Value-Values from CRA Table 4-11. These values are based on inventory assumptions.

4. Cellulose, Plastic, Rubber Materials (CPR) includes CPR within the waste, container materials and emplacement materials.

5. Fe-Metals include both materials in the waste and containers in total.
} 


\section{Table 3: Waste Emplacement Summary Report}

6. There is no decay correction for the listed isotope activities.

\begin{tabular}{|c|c|c|c|c|c|}
\hline \multirow{14}{*}{$\begin{array}{l}\text { MgO and } \\
\text { Cellulose, Plastic } \\
\& \text { Rubber (CPR) } \\
\text { Mass Emplaced } \\
\text { Per Waste Panel }\end{array}$} & Panel & Room & MgO (kg) & $\mathrm{CPR}^{*}(\mathrm{~kg})$ & Excess Factor \\
\hline & 1 & all & $4,482,356$ & $1,237,685$ & 1.79 \\
\hline & 2 & $2-7$ & $5,972,300$ & $1,241,909$ & 2.23 \\
\hline & 2 & 1 & 691,515 & 186,200 & 1.71 \\
\hline & 3 & 7 & 960,120 & 104,831 & 4.03 \\
\hline & 3 & 6 & 954,405 & 228,033 & 1.95 \\
\hline & 3 & 5 & $1,022,985$ & 284,651 & 1.70 \\
\hline & 3 & 4 & 960,120 & 255,054 & 1.79 \\
\hline & 3 & 3 & 931,545 & 243,860 & 1.89 \\
\hline & 3 & 2 & 944,880 & 227,889 & 2.03 \\
\hline & 3 & 1 & 662,940 & 183,072 & 1.76 \\
\hline & 4 & 7 & 948,690 & 248,924 & 1.91 \\
\hline & 4 & 6 & 457,200 & 125,282 & 1.83 \\
\hline & 4 & 5 & $0^{*}$ & 2,313 & .00 \\
\hline
\end{tabular}


Table 4: Performance Assessment, Software, and Hardware Changes

July 1, 2006, through June 30, 2007 
Table 4: Performance Assessment, Software, and Hardware Changes

\begin{tabular}{|c|c|c|c|}
\hline $\begin{array}{l}\text { WIPP Use Codes/Software, } \\
\text { Procedure and Code Version }\end{array}$ & Version Date & Description of Changes & Replacement Code Version/Use \\
\hline PHREEQCI Version 2.12.5-669 & $9 / 21 / 06$ & New Code & Well Monitoring Analysis \\
\hline EQ 3/6 Version 8.0 & 9/19/06 & New Code Version & Replaces EQ3/6 7.2c \\
\hline JAS3D Version 2.2.A & $8 / 28 / 06$ & New Code Version & Replaces JAS3D 2.0F \\
\hline nSIGHTS & $2 / 5 / 06$ & Version update (replaces Version 2.00). & $\begin{array}{l}\text { Version } 2.40 \text {. Used to calculate Culebra } \\
\text { transmissivity. }\end{array}$ \\
\hline NONLIN 2.0 & $01 / 12 / 07$ & $\begin{array}{l}\text { Regression tested and installed on VMS } \\
8.2\end{array}$ & NONLIN 2.0 Update \\
\hline NUMBERS 1.19 & $01 / 12 / 07$ & $\begin{array}{l}\text { New version of code to remove unused } \\
\text { variables, expand input character width } \\
\text { and coordinate names. }\end{array}$ & NUMBERS 1.22 \\
\hline PREBRAG 7.00 & $03 / 20 / 07$ & $\begin{array}{l}\text { New version of code to work with new } \\
\text { version of BRAGFLO. }\end{array}$ & PREBRAG 8.00 \\
\hline BRAGFLO 4.10 & $02 / 06 / 07$ & Retired per NP 19-1 & BRAGFLO 6.0 \\
\hline CCD2STEP 1.08 & $02 / 06 / 07$ & Retired and removed from system. & N/A \\
\hline CCDFGF 5.01A & $02 / 06 / 07$ & Retired per NP 19-1 & CCDFGF 5.02 \\
\hline CUTTINGS_S 6.01 & $02 / 06 / 07$ & Retired per NP 19-1 & CUTTINGS_S 6.02 \\
\hline CUTTINGS_S 5.10 & $02 / 06 / 07$ & Retired per NP 19-1 & CUTTINGS_S 6.02 \\
\hline DRSPALL 1.0 & $02 / 06 / 07$ & Retired per NP 19-1 & DRSPALL 1.10 \\
\hline EPAUNI 1.15 & $02 / 06 / 07$ & Retired per NP 19-1 & EPAUNI 1.15A \\
\hline GENII-A 2.10 & $02 / 06 / 07$ & Retired and removed from system. & N/A \\
\hline JAS3D 2.0F & $02 / 06 / 07$ & Retired per NP 19-1 & JAS3D 2.2.A \\
\hline LHS 2.41 & $02 / 06 / 07$ & Retired per NP 19-1 & LHS 2.42 \\
\hline nSIGHTS 2.0 & $02 / 06 / 07$ & Retired per NP 19-1 & NSIGHTS 2.4 \\
\hline
\end{tabular}


Table 4: Performance Assessment, Software, and Hardware Changes

\begin{tabular}{|c|c|c|c|}
\hline $\begin{array}{l}\text { WIPP Use Codes/Software, } \\
\text { Procedure and Code Version }\end{array}$ & Version Date & Description of Changes & Replacement Code Version/Use \\
\hline NUCPLOT 1.20 & $02 / 06 / 07$ & Retired and removed from system. & N/A \\
\hline NUTS 2.05B & $02 / 06 / 07$ & Retired per NP 19-1 & NUTS 2.05C \\
\hline PANEL 4.02 & $02 / 06 / 07$ & Retired per NP 19-1 & PANEL 4.03 \\
\hline PATTRN 1.00 & $02 / 06 / 07$ & Retired and removed from system. & N/A \\
\hline POSTGENII 4.20 & $02 / 06 / 07$ & Retired and removed from system. & N/A \\
\hline POSTLHS 4.07 & $02 / 06 / 07$ & Retired per NP 19-1 & POSTLHS 4.07A \\
\hline PREBRAG 6.00 & $02 / 06 / 07$ & Retired per NP 19-1 & PREBRAG 7.00 \\
\hline PREBRAG 6.40 & $02 / 06 / 07$ & Retired per NP 19-1 & PREBRAG 7.00 \\
\hline PRECCDFGF 1.00D & $02 / 06 / 07$ & Retired per NP 19-1 & PRECCDFGF 1.01 \\
\hline PREGENII 6.30 & $02 / 06 / 07$ & Retired and removed from system. & N/A \\
\hline QA ONLINE ALPHA & $02 / 06 / 07$ & Retired and removed from system. & N/A \\
\hline SECOTP2D 1.41 & $02 / 06 / 07$ & Retired per NP 19-1 & SECOTP2D 1.41A \\
\hline SUMMARIZE 2.20 & $02 / 06 / 07$ & Retired per NP 19-1 & SUMMARIZE 3.01 \\
\hline CAMCON_LIB 2.20 & $02 / 06 / 07$ & Retired per NP 19-1 & CAMCON_LIB 2.21 \\
\hline CAMDAT_LIB 1.25 & $02 / 06 / 07$ & Retired per NP 19-1 & CAMDAT_LIB 1.26 \\
\hline BRAGFLO 5.0 & $04 / 05 / 07$ & $\begin{array}{l}\text { New Version of Code: Modified to include } \\
\text { water budget and solids production. Code } \\
\text { robustness was improved. }\end{array}$ & BRAGFLO 6.0 \\
\hline POSTBRAG 4.00 & $04 / 09 / 07$ & $\begin{array}{l}\text { New Version of Code: A one-line change } \\
\text { to correctly size an array was made. }\end{array}$ & POSTBRAG 4.00A \\
\hline
\end{tabular}




\section{Conclusion}

The DOE believes the changes reported in this version of the WIPP Annual Change Report do not represent significant changes pertaining to the disposal system.

\section{References}

Delaware Basin Monitoring Annual Report, DOE/WIPP 99-2308, Revision \#7, September, 2006.

Brush et al. 2006, Consumption of Carbon Dioxide by Precipitation of Carbonate Minerals Resulting from Dissolution of Sulfate Minerals in the Salado Formation in Response to Microbial Sulfate Reduction in the WIPP.

Waste Isolation Pilot Plant 2005 Site Environmental Report, DOE/WIPP 2005-2225, September, 2006.

WIPP Subsidence Monument Leveling Survey, DOE/WIPP 07-2293, December, 2006. 